\title{
Phenotypic and Molecular Diversity of Native Chicken Genetic Groups in the Philippines
}

\author{
Jeremy Christian Q. Santiago ${ }^{1}$,* Hazel H. Achuela ${ }^{1}$, Don Carlo R. Batara ${ }^{1}$, Peter \\ James I. Gann ${ }^{1}$, Elmer C. Vingua ${ }^{2}$, Renee Christopher C. Cacho², Ma. Joy Theresa \\ T. Agcaoili ${ }^{1}$, Roylesther S. Aguinaldo ${ }^{1}$, Ryan Dave Q. Calventas ${ }^{1}$, Luis Augustus G. \\ Palafox $^{1}$, Benito B. Balneg ${ }^{1}$ and Mary Cris H. Calpito ${ }^{2}$
}

${ }^{1}$ Mariano Marcos State University, City of Batac, 2906 Ilocos Norte, Philippines

${ }^{2}$ Pangasinan State University - Sta. Maria Campus, Sta. Maria, 2440 Pangasinan, Philippines

*Corresponding author. Email: santiagojeremyy@yahoo.com

\begin{abstract}
The present study aims to evaluate the phenotypic and genotypic diversity of the 230 heads of chicken which were randomly sampled from the six native chicken genetic groups (Bolinao, Boholano, Darag Camarines, Paraoakan, and Zampen). The data on qualitative traits of the native chickens were tabulated and frequency distribution was computed. The quantitative traits were analyzed using Statistical Tool for Agricultural Research (STAR). Bolinao exhibits the most diverse qualitative characteristics. Morphometric body measurements are significantly different across genetic groups. Fifteen microsatellite or simple sequence repeats (SSR) recommended by Food and Agriculture Organization (FAO), were used for genetic characterization. Phylogenetic analysis of the six genetic groups of native chicken based on Nei's (1972) genetic distance showed that Bolinao and Darag native chicken are of closer genetic relationship as compared to the other five genetic groups studied. The genetic diversity was assessed using the POPGENE software. The high mean number of alleles per locus, moderately high observed heterozygosity and expected heterozygosity, positive inbreeding coefficient, and high fixation coefficient of a subpopulation within the total population values indicate high diversity of the different genetic groups of Philippine native chicken.
\end{abstract}

Keywords: Bolinao, native chicken, phenotypic, genotypic, microsatellite

\section{INTRODUCTION}

The Philippines has a number of chicken genetic groups which are mostly are of nondescript indigenous type. These indigenous chickens include Darag from Panay Island, Zampen from Zamboanga Peninsula, Camarines from Bicol, Paraoakan from Palawan, Boholano from Bohol, Joloanon from Basilan, Egon from Sorsogon, Patani from CARAGA, and Banaba from Batangas.

Bolinao native chicken is a unique genetic group in the Ilocos region which is predominant in the province of Pangasinan. However, this genetic group was found to be in small number. This may be attributed to indiscriminate breeding with exotic lines in different upgrading activities crossbreeding, replacement by commercial breeds or simply they are being neglected. Hence, conservation measures must be implemented, and these native chickens of have to be protected from extinction through intensive breeding programs, both at the species and population levels. Before starting a breeding program, however, one has to accomplish phenotypic and genotypic characterizations of the remaining populations and it usually include coming up with comprehensive phenotypic records, breeding history, as well as determination of genetic variation and 
distances. Although some authors reviewed native chicken's characteristics, breed types and genetic diversity $[1,6,7]$, more localized studies are needed to create a complete picture of native chicken diversity of the Philippines [8]. Investigation on the phenotypic characteristics and assessment on the management practices of Bolinao chicken had been previously conducted by Lambio [6]. However, the study was concentrated only in Pangasinan and other provinces in Ilocos region were not included. Moreover, no study had been conducted to determine the genetic makeup with respect to genetic variability and genetic relationship of Bolinao native chicken to other native chicken genetic groups at the molecular level.

\section{METHODOLOGY}

\subsection{Population and Sample}

On-farm investigations and surveys were conducted using a pre-drafted and pre-tested questionnaire as recommended by FAO [3]. A total of 230 samples representing Bolinao $(n=50)$, Paraoakan $(n=40)$, Darag $(n=40)$, Boholano $(n=40)$, Zampen $(n=30)$ and Camarines $(n=30)$ were randomly chosen in this study. The samples were collected from Pangasinan, Villaverde Farm in Abra, Iloilo, Bohol, Zamboanga Peninsula and Bicol (Additional File 1: Fig. 1). The sample size was predetermined based on FAO recommendation to include at least 10-30 and 100-300 sexually mature male and female chickens, respectively when doing phenotypic characterization studies.

\subsection{Phenotypic Characterization}

\subsubsection{Data collection}

All the chickens in each breeder farmers were measured and characterized. Quantitative traits that were measured in the mature birds included body length, shank length, wingspan and chest circumference. The discrete characters were evaluated that includes the comb type, plumage (morphology, pattern and color), and colors of the shank, skin, eye and ear lobe [5].

\subsubsection{Data analysis}

The data on qualitative traits of the native chickens were tabulated and frequency distribution was computed. The quantitative traits were analyzed using Statistical Tool for Agricultural Research (STAR, Ver. 2.1).

\subsection{Genetic Characterization}

\subsubsection{Blood sampling and DNA extraction}

Fresh blood samples were extracted from the wing vein of the chickens with proper physical restraint. Blood samples (1cc) were placed in EDTA-containing vacutainer tubes. The genomic DNA was extracted using salting-out method. The quality and quantity of the DNA samples were evaluated by gel electrophoresis and fluorometry (QuantusPromega ${ }^{\mathrm{TM}}$ ) prior to microsatellite analysis.

\subsubsection{PCR amplification and analysis}

For DNA amplification, 15 SSR primer sets recommended by FAO were used for this study (See Additional File 2: Table 1). PCR amplification was carried out in a volume of $20 \mu \mathrm{l}$ containing, $1 \mathrm{x}$ PCR buffer, $5.0 \mathrm{mM} \mathrm{MgCl}_{2}, 0.35 \mathrm{mM}$ dNTP, $0.25 \mu \mathrm{M}$ of each primer and $0.6 \mathrm{U}$ Taq polymerase. PCR reactions were performed in a thermal cycler: an initial step of $5 \mathrm{~min}$ at $94^{\circ} \mathrm{C}, 35$ cycles of $45 \mathrm{sec}$ at $94^{\circ} \mathrm{C}$, annealing temperature for $45 \mathrm{sec}$, and $45 \mathrm{sec}$ at $72^{\circ} \mathrm{C}$, and a final step of $10 \mathrm{~min}$ at $72^{\circ} \mathrm{C}$. The PCR products were separated and visualized in agarose gel in $0.5 \mathrm{x}$ TBE buffer by gel red staining.

\subsubsection{Data analysis}

The genetic diversity of each chicken group was assessed by calculating the number of alleles per locus and its mean (MNA), observed heterozygosity (Ho), and unbiased expected heterozygosity (He), using the POPGENE v.3.2 [12].

The degree of heterozygosity represents the mean percentage of heterozygous loci per individual or the mean percentage of heterozygous individuals in a population. Estimation of the heterozygosity degree is important to know genetic variability and to determine the level of polymorphism of alleles. High heterozygosity shows high genetic diversity within a population. If the observed heterozygosity (Ho) is much lower compared to that value of expected heterozygosity $(\mathrm{He})$, it might indicate a more intense selection or a higher degree of inbreeding. Estimation of genotypic diversity in heterozygosity of microsatellite markers were previously used for determining animal breed selection. For the animal traceability, $\mathrm{He}>0.6$ are the most reasonable informative locus for application in genetics. Genetic distance, also known as F-statistics such as fixation coefficient of an individual within a subpopulation ( $\mathrm{F}_{\mathrm{IS}}$ ), fixation coefficient of an individual within the total population $\left(\mathrm{F}_{\mathrm{IT}}\right)$ and fixation coefficient of a subpopulation within the total population $\left(\mathrm{F}_{\mathrm{ST}}\right)$ per locus were also calculated using the same software. Shannon's Information Index (I), an indicator of genetic diversity, represents the effectiveness of the markers 
used to reveal variations thus indicate broad diversity of populations. To illustrate the genetic distances between and among populations, the phylogenetic tree was constructed based on Nei's genetic distance. The method used was the UPGMA (Modified from NEIGHBOR procedure of PHYLIP version 3.5) with a bootstrap value of 1000 .

\section{RESULTS}

\subsection{Phenotypic Characterization}

A total of 230 birds were sampled, observed, and recorded their phenotypic characteristics.

\subsubsection{Discrete characteristics}

\subsubsection{Feather morphology and distribution.}

Feather morphology and distribution of the six groups of native chicken are all normal.

\subsubsection{Plumage pattern}

The plumage pattern of all the hens and roosters of Boholano and Zampen is plain while the Camarines chicken is laced. On the other hand, most of the hens of Paraoakan have spangled plumage pattern while most of the roosters are plain. Moreover, all the hens of Darag chicken have pencilled while all the roosters have plain plumage pattern. Meanwhile, the Bolinao chicken has varied plumage pattern but majority have plain plumage pattern.

\subsubsection{Plumage color}

The plumage color for both hens and roosters of Darag, Boholano and Zampen are all wheaten, red, and black, respectively. The Paraoakan roosters have mostly black plumage while the hens have mostly white. On the other hand, majority of the Camarines hen have brown plumage while the roosters have mostly red plumage. Moreover, majority of the Bolinao roosters have red plumage while the plumage color of the hens is diversified but mostly exhibited wheaten plumage.

\subsubsection{Earlobe color}

Darag and Camarines have white earlobe colors including the majority of the hens of Paraoakan and Boholano. Zampen exhibit red colors which is also the dominant earlobe color for to the roosters of Paraoakan and Boholano. Meanwhile, the earlobe color of most of the Bolinao hens is red while the rooster is either white or red.

\subsubsection{Comb type}

The comb type exhibited by Darag and Zampen are single and pea, respectively. The dominant comb type observed in Paraoakan, Boholano and Camarines is also single. On the other hand, the comb type of Bolinao is varied, from rose to single or pea.

\subsubsection{Comb size}

All the hens and majority of the roosters of Camarines have small comb size. On the other hand, all the Paraoakan roosters and majority of the hens exhibit medium and small comb size, respectively. The comb size of Darag hen are mostly medium and the roosters are mostly large Mostly of the sampled Bolinao chicken have small combs.

\subsubsection{Shank color}

The shank color for both hens and roosters of Zampen and Camarines are grey and white, respectively. On the other hand, the shank color of Darag and Paraoakan is mostly black while the other samples are green, white or yellow. Meanwhile, the shank color of Boholano and Bolinao are highly diversified.

\subsubsection{Skin color}

Majority of Bolinao exhibited white skin color including all the hens and roosters of the other 5 genetic groups of native chicken.

\subsubsection{Iris color}

The dominant iris color of the six genetic groups of native chicken is orange.

\subsubsection{Morphometric traits}

There are significant differences in the morphometric features such as the body length, wing span, shank length and chest circumference among the six genetic groups of native chicken in the Philippines. The coefficients of variation among the measured characteristics of these native chickens' ranges from 8.52 to 18.44 (Tables $1-2$ ).

\subsubsection{Body length}

Zampen has the longest body but it is comparable with the body lengths of Camarines and Boholano. The body of the roosters of these groups of chicken is significantly longer than the body lengths of Bolinao, Darag and Paraoakan. On the other hand, Paraoakan hens have significantly shorter body length than the hens of other genetic groups. 


\subsubsection{Wing span}

Camarines roosters and Boholano hens have the widest wing span among the six genetic groups of native chicken considered in this study. However, they are statistically the same with that of Bolinao, Darag, and Paraoakan. Both the wing span of the roosters and hens of Zampen was significantly the shortest among the six groups.

\subsubsection{Shank length}

The shanks of Zampen are the longest but they are not significantly different with Boholano, Bolinao and Paraoakan. Camarines and Darag have comparable shank lengths which are significantly shorter shanks than Zampen. The Camarines group of native chicken exhibits the shortest shanks.

\subsubsection{Chest circumference}

The roosters of the Paraoakan group of native chicken have the widest chest circumference. They are significantly larger than the roosters of Boholano but comparable with Bolinao, Camarines, Darag and Zampen. On the other hand, the chest circumference of Bolinao hens is the largest, followed by Paraoakan then Zampen and Darag. The Camarines hens exhibit the smallest chest circumference.

Table 1. Mean comparison on the morphometric features of roosters from the six genetic groups of native chicken in the Philippines used in the study.

\begin{tabular}{|c|c|c|c|c|}
\hline $\begin{array}{l}\text { Genetic } \\
\text { Group }\end{array}$ & $\begin{array}{c}\text { Body } \\
\text { Length } \\
\text { (cm) }\end{array}$ & $\begin{array}{l}\text { Wing } \\
\text { Span } \\
(\mathbf{c m})\end{array}$ & $\begin{array}{c}\text { Shank } \\
\text { Length } \\
\text { (cm) }\end{array}$ & $\begin{array}{c}\text { Chest } \\
\text { Circumference } \\
(\mathrm{cm})\end{array}$ \\
\hline $\begin{array}{c}\text { Bolınao } \\
(\mathrm{n}=12)\end{array}$ & $26.44^{\mathrm{b}}$ & $64.25^{\mathrm{a}}$ & $8.44^{\mathrm{ab}}$ & $32.25^{\mathrm{ab}}$ \\
\hline $\begin{array}{l}\text { Darag } \\
(n=20)\end{array}$ & $26.39^{b}$ & $63.40^{\mathrm{a}}$ & $8.30^{\mathrm{b}}$ & $31.87^{\mathrm{ab}}$ \\
\hline $\begin{array}{l}\text { Bohola } \\
\text { no } \\
(n=20)\end{array}$ & $36.86^{\mathrm{a}}$ & $67.07^{\mathrm{a}}$ & $8.93^{\mathrm{ab}}$ & $27.93^{b}$ \\
\hline $\begin{array}{l}\text { Camari } \\
\text { nes } \\
(n=10)\end{array}$ & $42.33^{\mathrm{a}}$ & $68.00^{\mathrm{a}}$ & $7.33^{b}$ & $31.33^{\mathrm{ab}}$ \\
\hline $\begin{array}{l}\text { Paraoa } \\
\text { kan } \\
(n=11)\end{array}$ & $26.50^{\mathrm{b}}$ & $63.33^{\mathrm{a}}$ & $8.77^{\mathrm{ab}}$ & $37.00^{\mathrm{a}}$ \\
\hline $\begin{array}{l}\text { Zampe } \\
\mathbf{n} \\
(\mathrm{n}=15)\end{array}$ & $43.00^{\mathrm{a}}$ & $45.00^{\mathrm{b}}$ & $11.00^{\mathrm{a}}$ & $31.00^{\mathrm{ab}}$ \\
\hline$\% \mathrm{CV}$ & $\begin{array}{l}9.92 \\
* * *\end{array}$ & $\begin{array}{l}8.27 \\
* * *\end{array}$ & $\begin{array}{c}12.83 \\
* *\end{array}$ & $\begin{array}{c}12.08 \\
* *\end{array}$ \\
\hline Significance & & & & \\
\hline
\end{tabular}

Means marked with the same letter superscript are not significantly different using Tukey's HSD Test.
$* *$ significant at $1 \%$
$* * *$ significant at $0.1 \%$

Among the six genetic groups of native chicken, Zampen roosters and hens were observed to have the longest body and shank while Camarines roosters and Boholano hens have the widest wing span. Meanwhile, the chest circumference of Paraoakan rooster and Bolinao hens are the largest.

\subsection{Genetic Characterization}

\subsubsection{Genetic Diversity within Populations}

All the six genetic groups of native chicken had higher observed number of alleles than the effective number of alleles (Table 3). This indicates that the populations already met the required number of alleles needed to achieve the average heterozygosity, hence, the excess alleles are considered negligible. Moreover, the high allelic diversity indicates sufficient genetic variability existing in the population despite the decreasing population of native chickens as well as the non-random mating practiced by breeders/native chicken raisers. Also, the high I values suggest that the markers used were effective in revealing these variations. There is indeed broad or wide diversity within the six genetic groups.

Table 2. Mean comparison on the morphometric features of hens from the six genetic groups of native chicken in the Philippines used in the study.

\begin{tabular}{|c|c|c|c|c|}
\hline $\begin{array}{l}\text { Genetic } \\
\text { Group }\end{array}$ & $\begin{array}{c}\text { Body } \\
\text { Length } \\
(\mathbf{c m})\end{array}$ & $\begin{array}{l}\text { Wing } \\
\text { Span } \\
(\mathrm{cm}) \\
\end{array}$ & $\begin{array}{l}\text { Shank } \\
\text { Length } \\
(\mathbf{c m})\end{array}$ & $\begin{array}{l}\text { Chest } \\
\text { Circumference } \\
(\mathbf{c m}) \\
\end{array}$ \\
\hline $\begin{array}{c}\text { Bolinao } \\
(n=38)\end{array}$ & $27.34^{\mathrm{bc}}$ & $51.58^{\mathrm{ab}}$ & $7.83^{\mathrm{ab}}$ & $31.45^{\mathrm{a}}$ \\
\hline $\begin{array}{l}\text { Darag } \\
(n=20)\end{array}$ & $23.49^{\mathrm{cd}}$ & $54.60^{\mathrm{a}}$ & $6.55^{\mathrm{bc}}$ & $28.93^{\mathrm{ab}}$ \\
\hline $\begin{array}{c}\text { Boholano } \\
(n=20)\end{array}$ & $36.50^{\mathrm{a}}$ & $63.56^{\mathrm{a}}$ & $7.75^{\mathrm{ab}}$ & $26.81^{b}$ \\
\hline $\begin{array}{c}\text { Camarines } \\
\quad(n=20)\end{array}$ & $33.55^{\mathrm{ab}}$ & $57.45^{\mathrm{a}}$ & $5.36^{c}$ & $26.73^{b}$ \\
\hline $\begin{array}{c}\text { Paraoakan } \\
(n=29)\end{array}$ & $18.15^{\mathrm{d}}$ & $58.94^{\mathrm{a}}$ & $7.96^{\mathrm{a}}$ & $30.97^{\mathrm{ab}}$ \\
\hline $\begin{array}{c}\text { Zampen } \\
(n=15)\end{array}$ & $39.00^{\mathrm{a}}$ & $41.00^{\mathrm{b}}$ & $9.00^{\mathrm{a}}$ & $29.00^{\mathrm{ab}}$ \\
\hline$\% \mathrm{CV}$ & $\begin{array}{c}18.44 \\
* * *\end{array}$ & $\begin{array}{c}14.21 \\
* * *\end{array}$ & $\begin{array}{c}11.05 \\
* * *\end{array}$ & $\begin{array}{c}11.08 \\
*\end{array}$ \\
\hline \multicolumn{5}{|l|}{ Significance } \\
\hline \multicolumn{5}{|c|}{$\begin{array}{l}\text { Means marked with the same letter superscript are not } \\
\text { significantly different using Tukey's HSD Test. } \\
\text { ** significant at } 1 \% \\
* * * \text { significant at } 0.1 \%\end{array}$} \\
\hline
\end{tabular}


Table 3. Mean (Na) and effective (Ne) number of alleles, Shannon's index (1), observed heterozygosity (Ho), expected heterozygosity (He) as observed within the six native chicken genetic groups at fifteen microsatellite loci.

\begin{tabular}{|c|c|c|c|c|c|}
\hline & na & $\begin{array}{c}\text { ne } \pm \\
\text { SD }\end{array}$ & $\mathbf{I} \pm \mathbf{S D}$ & $\begin{array}{c}\text { Ho } \pm \\
\text { SD }\end{array}$ & $\begin{array}{c}\mathrm{He} \pm \\
\text { SD }\end{array}$ \\
\hline \multirow[t]{3}{*}{ Bolinao } & 2.93 & 2.1058 & 0.8328 & 0.3971 & 0.5019 \\
\hline & & \pm & \pm & \pm & \pm \\
\hline & & 0.5130 & 0.1932 & 0.3231 & 0.1248 \\
\hline \multirow[t]{3}{*}{ Darag } & 2.60 & 1.8684 & 0.6541 & 0.2491 & 0.4076 \\
\hline & & \pm & \pm & \pm & \pm \\
\hline & & 0.5071 & 0.5885 & 0.3138 & 0.2139 \\
\hline \multirow[t]{3}{*}{ Paraoakan } & 2.27 & 1.6334 & 0.5529 & 0.2500 & 0.3572 \\
\hline & & \pm & \pm & \pm & \pm \\
\hline & & 0.3600 & 0.2281 & 0.2106 & 0.2106 \\
\hline \multirow[t]{3}{*}{ Boholano } & 3.07 & 2.7742 & 1.0567 & 0.1600 & 0.6403 \\
\hline & & \pm & \pm & \pm & \pm \\
\hline & & 0.2960 & 0.0857 & 0.1831 & 0.0470 \\
\hline \multirow[t]{3}{*}{ Zampen } & & 2.5377 & 1.0059 & 0.0897 & 0.6037 \\
\hline & & \pm & \pm & \pm & \pm \\
\hline & 3.13 & 0.3519 & 0.3412 & 0.3412 & 0.3412 \\
\hline \multirow[t]{3}{*}{ Camarines } & & 1.8028 & 0.6606 & 0.2095 & 0.4352 \\
\hline & & \pm & \pm & \pm & \pm \\
\hline & 2.33 & 0.2762 & 0.1704 & 0.2825 & 0.1023 \\
\hline
\end{tabular}

na (observed number of alleles); ne (effective number of alleles); I (Shannon's information index);

Ho (observed heterozygosity; $\mathrm{He}$ (expected heterozygosity)

\subsubsection{Genetic Variation across Populations}

Genetic variation describes the naturally occurring genetic differences among individuals of the same species. This variation permits flexibility and survival of a population in the face of changing environmental circumstances.

There were a total of 47 alleles detected in all loci, each having three to four alleles which are already sufficient to meet the average heterozygosity of the populations (Table 4). This indicates that there is allelic diversity across populations. This confirms the diversities observed in the phenotypic characteristics of the six genetic groups.
Table 4. Summary of genetic variation statistics for all loci across the six native chicken genetic groups studied.

\begin{tabular}{lccc}
\hline \multicolumn{1}{c}{ Locus } & na* $^{*}$ & ne$^{*}$ & I* \\
\hline ADL0268 & 3.00 & 2.3402 & 0.9245 \\
ADL0278 & 3.00 & 2.2376 & 0.9307 \\
MCW0248 & 3.00 & 2.7250 & 1.0428 \\
MCW0295 & 3.00 & 2.5438 & 0.9945 \\
MCW0081 & 3.00 & 2.9637 & 1.0926 \\
MCW0069 & 3.00 & 2.4294 & 0.9794 \\
MCW0034 & 3.00 & 2.3013 & 0.9346 \\
LEI0166 & 3.00 & 2.1967 & 0.9184 \\
MCW0111 & 3.00 & 1.9211 & 0.8311 \\
MCW0014 & 3.00 & 2.0865 & 0.8961 \\
MCW0183 & 3.00 & 2.6749 & 1.0353 \\
LEI0234 & 4.00 & 3.1680 & 1.2010 \\
MCW0104 & 4.00 & 2.8170 & 1.1053 \\
MCW0123 & 3.00 & 2.3584 & 0.9351 \\
MCW0165 & 3.00 & 2.3485 & 0.9636 \\
\hline \multicolumn{5}{c}{ Mean } & 3.13 & 2.4741 & 0.9857 \\
St. Dev & 0.3519 & 0.3396 & 0.0952 \\
\hline \multicolumn{5}{c}{ na = Observed number of alleles } \\
Crow (1964)] $=$ Effective number of alleles [Kimura and \\
I = Shannon's Information index [Lewontin (1972)
\end{tabular}

\subsubsection{Heterozygosity}

The summary of heterozygosity statistics for each locus across the six native chicken genetic groups studied is shown in Table 5. The results showed that the average observed heterozygosity was lesser than the expected heterozygosity (He).

All Polymorphism Information Content (PIC) values were above 0.50 except for MCW0111. Following the criteria of Botstein et al. [2], 93\% of the investigated markers were, in general, highly informative (PIC > $0.5)$. Hence, the average value of 0.59 for the PIC indicated abundant genetic diversity across the populations. The high PIC value further indicated that these markers are useful for population assignment.

Table 5. Summary of heterozygosity statistics as observed for each locus across the six native chicken genetic groups studied.

\begin{tabular}{lllll}
\hline Locus & Ho & He & PIC & $\begin{array}{l}\text { Ave. } \\
\text { H }\end{array}$ \\
\hline ADL0268 & 0.1839 & 0.5735 & 0.5727 & 0.4318 \\
ADL0278 & 0.1322 & 0.5539 & 0.5531 & 0.3642 \\
MCW0248 & 0.2011 & 0.6339 & 0.6330 & 0.4782 \\
MCW0295 & 0.1695 & 0.6078 & 0.6068 & 0.5246 \\
MCW0081 & 0.1322 & 0.6635 & 0.6626 & 0.5506 \\
MCW0069 & 0.2557 & 0.5892 & 0.5884 & 0.5482 \\
MCW0034 & 0.2270 & 0.5663 & 0.5655 & 0.5445 \\
LEI0166 & 0.1580 & 0.5456 & 0.5447 & 0.4633 \\
MCW0111 & 0.0374 & 0.4801 & 0.4794 & 0.4079
\end{tabular}




\begin{tabular}{lllll} 
MCW0014 & 0.0431 & 0.5215 & 0.5208 & 0.4051 \\
MCW0183 & 0.4799 & 0.6271 & 0.6466 & 0.5606 \\
LEI0234 & 0.4914 & 0.6853 & 0.6846 & 0.5564 \\
MCW0104 & 0.4109 & 0.6459 & 0.6852 & 0.5574 \\
MCW0123 & 0.0546 & 0.5768 & 0.5760 & 0.4965 \\
MCW0165 & 0.0029 & 0.5750 & 0.5747 & 0.4110 \\
\hline \multirow{2}{*}{ Mean } & 0.1987 & 0.5897 & 0.5863 & 0.4867 \\
& & & & \\
St. Dev & 0.1546 & 0.1546 & 0.0562 & 0.0683 \\
\hline
\end{tabular}

\subsubsection{F-Statistics and Gene Flow}

Table 6 presents the summary of the F statistics and gene flow for all loci across the six genetic groups of native chicken. There is an average of 0.17 expected reduction in heterozygosity across populations when compared to Hardy-Weinberg expectation.

Table 6. Summary of F-Statistics and gene flow for all loci across the six native chicken genetics groups studied.

\begin{tabular}{|c|c|c|c|c|}
\hline Locus & $\mathbf{F}_{\text {IS }}$ & $\mathbf{F}_{\text {IT }}$ & F $_{\text {ST }}$ & $\mathrm{Nm}^{*}$ \\
\hline ADL0268 & 0.5747 & 0.6785 & 0.2442 & 0.7739 \\
\hline ADL0278 & 0.6348 & 0.7595 & 0.3415 & 0.4822 \\
\hline MCW0248 & 0.5811 & 0.6835 & 0.2443 & 0.7734 \\
\hline MCW0295 & 0.6734 & 0.7174 & 0.1347 & 1.6064 \\
\hline MCW0081 & 0.7591 & 0.7998 & 0.1690 & 1.2289 \\
\hline MCW0069 & 0.5339 & 0.5649 & 0.0666 & 3.5032 \\
\hline MCW0034 & 0.5833 & 0.5981 & 0.0356 & 6.7698 \\
\hline LEI0166 & 0.6595 & 0.7101 & 0.1485 & 1.4333 \\
\hline MCW0111 & 0.9102 & 0.9232 & 0.1451 & 1.4733 \\
\hline MCW0014 & 0.8959 & 0.9192 & 0.2238 & 0.8671 \\
\hline MCW0183 & 0.1436 & 0.2327 & 0.1041 & 2.1523 \\
\hline LEI0234 & 0.1122 & 0.2779 & 0.1866 & 1.0896 \\
\hline MCW0104 & 0.2603 & 0.3600 & 0.1348 & 1.6047 \\
\hline MCW0123 & 0.8908 & 0.9060 & 0.1394 & 1.5430 \\
\hline MCW0165 & 0.9929 & 0.9949 & 0.2857 & 0.6252 \\
\hline Mean & 0.5912 & 0.6619 & 0.1729 & 1.1956 \\
\hline
\end{tabular}

\subsubsection{Genetic Distance}

Table 7 shows the Nei's original measures of genetic identity (above diagonal) and genetic distance (below diagonal) across genetic groups of native chicken (See additional file 9: Table 8). Paraoakan and Zampen record the highest genetic (0.5103) distance between the other genetic groups. Meanwhile, Bolinao and Darag are the least genetically distant among the other groups. This result is congruent to the genetic identity value and that Bolinao and Darag have the highest genetic identity value.

Table 7. Nei's original measures of genetic identity and genetic distance across six native chicken genetic groups.

\begin{tabular}{lcccccc}
\hline $\begin{array}{c}\text { Popul } \\
\text { ation }\end{array}$ & $\begin{array}{c}\text { Boli } \\
\text { nao }\end{array}$ & $\begin{array}{c}\text { Da } \\
\text { rag }\end{array}$ & $\begin{array}{c}\text { Parao } \\
\text { akan }\end{array}$ & $\begin{array}{c}\text { Boho } \\
\text { lano }\end{array}$ & $\begin{array}{c}\text { Zam } \\
\text { pen }\end{array}$ & $\begin{array}{c}\text { Cama } \\
\text { rines }\end{array}$ \\
\hline Bolin & - & 0.9 & 0.922 & 0.824 & 0.70 & 0.705 \\
ao & & 297 & 7 & 9 & 75 & 2 \\
Darag & 0.07 & - & 0.877 & 0.800 & 0.63 & 0.756 \\
& 29 & & 6 & 3 & 48 & 5 \\
Parao & 0.08 & 0.1 & - & 0.753 & 0.60 & 0.690 \\
akan & 05 & 306 & & 0 & 03 & 5 \\
Bohol & 0.19 & 0.2 & 0.283 & - & 0.90 & 0.767 \\
ano & 25 & 228 & 6 & & 65 & 4 \\
Zamp & 0.34 & 0.4 & 0.510 & 0.098 & - & 0.688 \\
en & 61 & 545 & 3 & 1 & & 8 \\
Cama & 0.34 & 0.2 & 0.370 & 0.264 & 0.37 & - \\
rines & 93 & 790 & 3 & 7 & 28 & \\
\hline
\end{tabular}

Nei's genetic identity (above diagonal) and genetic distance

(below diagonal).

\subsubsection{Phylogenetic Tree}

The dendrogram was constructed on the basis of genetic distance and neighbor-joining methods following un-weighted pair-group method using arithmetic averages.

There were 2 main nodes from which the six genetic groups evolved on the basis 15 microsatellite markers used in this study.

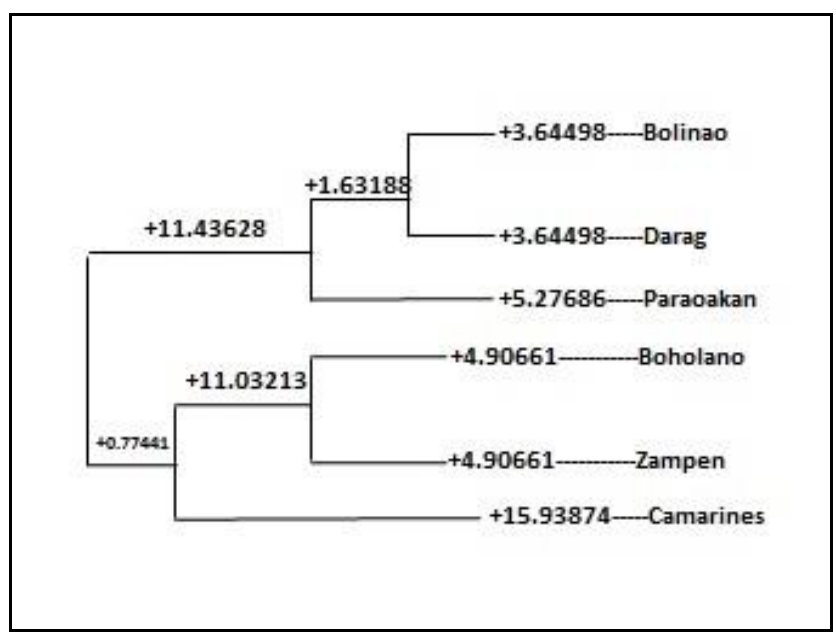

Figure 1. Phylogenetic analysis of the six genetic of native chicken based on Nei's (1972) Genetic distance: Bootstrap value: 1000 .

Bolinao and Darag are the least divergent among the other groups. This means that they are more genetically identical due to their common ancestral evolution. In contrast, Camarines formed a relatively different cluster.

\section{DISCUSSION}

\subsection{Phenotypic Characterization}




\subsubsection{Plumage pattern}

Diversities in plumage patterns can be attributed to feather developmental mechanisms, genes of chickens and raisers selection practices $[3,10]$. The color patterns were due to the distribution of eumelanin and the presence or absence of pheomelanin at feather developmental stage. The kind and concentration may vary among cells because of molecular gradients at the feather follicles. The position of feather in the body may also affect the expression of color pattern because of differences in intensity of melanin pigmentation in the skin. These are also governed by different gene actions [11]. Raisers may have retained chickens with attractive color patterns as replacement stocks.

\subsubsection{Plumage color}

The higher occurrences of red plumage among roosters and brown plumage in hens may be inherited from their progenitor - the red jungle fowl and through natural selection. These colors enable them to mimic dry leaves and debris which is important especially when threatened by dangers. This is the same with the chickens in Guimaras having black and slate plumages which make it easy for them to hide, when threatened, in the grey to black bark of mango trees. The preferences of raisers for other colors further increase diversity in plumage colors.

\subsubsection{Earlobe color}

The variation in the earlobe color may be due to ancestral lineages and mutations [3, 10]. The presence of white pigment in the earlobe was because of purine bases and not of melanin or carotenoid. It was inherited as a polygenic trait. The possibility of mutations on genes responsible for the expression of melanin and carotenoids was also considered given the occurrences of other earlobe colors [9]. The differences in the distribution of earlobe colors were due to the adaptability of chickens with specific earlobe color to local conditions.

\subsubsection{Comb type}

Duguma [4] stated that single comb was dominant among traditional chickens in tropical regions for it helps reduce $40 \%$ of body heat.

\subsubsection{Shank color}

According to Smyth [11] as cited by Salces [8], the diversity in shank color may be due to the interactions of major modifier genes. The homozygosity of the black extension factor (E) expresses the black shank. With the interaction of dermal melanin (id+) and $\mathrm{E}$ with dominant white (I), chickens will express slate or green shank. Moreover, the presence of autosomal white (W+) interacting with melanin will appear as blue or slate shank and the $w$ for green.

\subsubsection{Skin color}

The white skin originated from the red jungle fowl (G.gallus) while the yellow skin was from the grey jungle fowl (G. sonneratii). The diversity in skin color can be due to mode of inheritance and hybridization [8].

\subsubsection{Iris color}

The results on diversities of iris color may be attributed to the interactions of melanin and carotenoids, ingestion and utilization of xanthophylls, and its correlation with other genes expressing colors to other parts of the chicken body $[3,10]$. The diversity in iris color of hens can be due to the presence of carotenoids in ingested feeds and its utilization for egg yolk production as explained by Smyth [11]. The brighter colored iris of roosters can be due to excess carotenoids reacting with the melanin.

\subsection{Genetic Characterization}

\subsubsection{Genetic Diversity within Populations}

More specifically, Bolinao genetic group exhibited the highest observed heterozygosity among the six populations. This supports the high allelic diversity as illustrated in the table. With regards to the adaptation to changing environments, this is favorable because the individuals will be more likely to survive and reproduce. However, the allelic diversity should be of relatively lower value in order to achieve the purification of the Bolinao native chicken. This can be accomplished by a more intense selection and thereby the practice of nonrandom mating.

Despite the high allelic diversity, the six genetic groups have relatively lower Ho than He. This indicates that selection and non-random mating is currently being practiced until such time that the populations have already achieved the homozygosity level needed for it be considered a purified breed.

This genetic diversity within populations agrees with the diversities in phenotypic characters observed within the six genetic groups. Indeed, there is a need to perform a continuous selection and breeding of potential breeder stocks.

\subsubsection{Genetic Variation across Populations}

\subsubsection{Heterozygosity}

Various factors can contribute towards excess of homozygotes. First, the locus is under selection. Second, 
'null alleles' may be present which are leading to a false observation of excess homozygotes. Third, inbreeding may be common in the population. Fourth, the presence of population substructure may lead to Wahlunds' effect. The factor which might have influenced the heterozygote deficiency observed in the Bolinao population is inbreeding due to small population sizes and ignorance of chicken owners of scientific management. Also, the small population size may also indicate an intense form of selection.

The average value of 0.59 for the PIC indicated abundant genetic diversity across the populations. The high PIC value further indicated that these markers are useful for population assignment.

\subsubsection{F-Statistics and Gene Flow}

The mean value obtained for $\mathrm{Nm}$ based on $\mathrm{F}_{\mathrm{ST}}$ indicates that there is enough gene flow among the six genetic groups, negating the effects of genetic drift. The mean $\mathrm{F}_{\mathrm{ST}}=0.1729$ indicates that there is large (or high) genetic differentiation. This means that there is already an exchange of genes happening for all loci across populations. Among the 15 loci, 53\% of them have moderate genetic differentiation while less than half $(46 \%)$ have high genetic differentiation. Small genetic differentiation is observed in $6.67 \%$ of the loci (i.e, only locus MCW0034). F flow $(\mathrm{Nm})$. The mean $\mathrm{Nm}$, computed as the product of effective population size and migration rate, is 1.1956. Since mean $\mathrm{Nm}$ is greater than 1 , it can be said that there is enough gene flow happening across populations. However, looking into the individual locus, there is not enough gene flow observed across populations in $33 \%$ of the loci, namely loci ADL0268, ADL0278, MCW0248, MCW0014, and MCW0165, since the Nm values computed fall below 1 . There is an observed close genetic relationship among populations with regards to the locus MCW0034 which has an Nm value of 6.7698

\subsubsection{Genetic Distance}

The genetic distance between populations provides a relative estimate of the time elapsed since the subdivisions existed as a single population and helps in characterizing the breeds or lines. The genetic distance of such magnitude is predictable for the breeds which are not completely isolated from each other for a longer number of generations and they are also not subjected to differential selection pressures. The exchange of genes between populations homogenizes allele frequencies between populations and determines the relative effects of selection and genetic drift. Furthermore, the values reflect the result of and support the phylogenetic analysis wherein Bolinao and Darag are the least divergent among the other groups. This means that they are more genetically identical due to their common ancestral evolution. In contrast, Camarines formed a relatively different cluster.

\subsubsection{Phylogenetic Tree}

The phylogenetic tree shows that Bolinao and Darag might have frequent exchange of genes than the rest of the populations. This might be due to the fact that Bolinao was transported to Western Visayas, hence migration happened to and from the Darag population. Moreover, genetic relatedness between examined populations could be caused also by the fact that their selection was conducted in a similar way (similar type of breeding program). Also, similarities in the phenotypic characteristics might have also influenced the narrow genetic distance observed between the two populations.

\section{CONCLUSION}

The six genetic groups of native chicken are highly diverse in terms of phenotypic characteristics. Allelic variation statistics reveals that there is also high genetic diversity across populations. Bolinao had the highest genetic diversity which shows that there is still a need for a more intense selection to achieve more uniform population of Bolinao chickens. Bolinao and Darag are least genetically distant; thus, they are more genetically identical as compared to the other five genetic groups sampled in this study.

\section{AUTHORS' CONTRIBUTIONS}

Jeremy Christian Q. Santiago, Ma. Joy Theresa T. Agcaoili, Roylesther S. Aguinaldo, Ryan Dave Q. Calventas, Benito B. Balneg, Elmer C. Vingua, Renee Christopher C. Cacho, Luis Augustus G. Palafox, and Mary Cris H. Calpito collected data on phenotypic characterization and blood sample collection of the different genetic groups.

Ma. Joy Theresa T. Agcaoili, Roylesther S. Aguinaldo, Ryan Dave Q. Calventas performed the experiments and analyzed the data.

Jeremy Christian Q. Santiago, Hazel H. Achuela, Don Carlo R. Batara, Ma. Joy Theresa T. Agcaoili contributed to the interpretation of results and discussion.

Peter James I. Gann conceived and designed the analysis.

\section{ACKNOWLEDGMENT}

We extend our sincerest gratitude to Department of Science and Technology - Philippine Council for Agriculture, Aquatic and Natural Resources Research and Development (DOST-PCAARRD for funding this research. The Provincial Agriculture Offices and the 
Municipal Agriculturists from the different provinces, for assisting the research staff in field data gathering and sampling. We also acknowledge the administrative staff of Mariano Marcos State University (MMSU) and Pangasinan State University (PSU), for logistics support.

\section{REFERENCES}

[1] O. L. Bondoc, (1998). "Biodiversity of livestock and poultry genetic resources in the Philippines". IASCA/UPLB and PCARRD-DOST. https://ias.cafs.uplb.edu.ph/project/biodiversityof-livestock-and-poultry-genetic-resources-in-thephilippines/

[2] D. Botstein, R. L. White, M. Skolnick, and R. W. Davis, 1980. Construction of a genetic linkage map in man using restriction fragment length polymorphisms. Am. J. Hum. Genet. 32: 314-331. https://www.ncbi.nlm.nih.gov/pmc/articles/PMC16 86077/pdf/ajhg00189-0020.pdf

[3] J. C. J. Cabarles, A. L. Lambio, R. S. A. Vega, S. S. Capitan, and M.S. Mendioro, 2012. "Distinct morphological features of traditional chickens (Gallus gallus domesticus L) in Western Visayas, Philippines". Anim Genet Res 51: 7387.https://doi.org/10.1017/S2078633612000410

[4] R. Duguma 2006. Phenotypic characterization of some indigenous chicken ecotypes of Ethiopia. Livest Res Rural Dev 18(9): 131.https://www.researchgate.net/publication/2904 45509 Phenotypic characterization of some indi genous chicken ecotypes of Ethiopia

[5] FAO. 2012. "Phenotypic characterization of animal genetic resources". FAO Animal Production and Health Guidelines No. 11. Rome.http://www.fao.org/3/i2686e/I2686E.pdf
[6] A. L. Lambio, 2000. "Philippine native chickens". Philipp AgricSci83(1):

$112-$

17.https://agris.fao.org/agrissearch/search.do?recordID=PH2001101058

[7] A. L. Lambio. 2010. "Poultry production in the tropics". Quezon City: The University of the Philippines Press.

[8] J. P. Picardial, F. A. Afable, M.C. A. Lagman, E. A. Campoto, E. P. Palada, M. B. Valdez, "Phenotypic characterization of native chickens (Gallus gallus domesticus) in Eastern Samar, Philippines", Thomson R, vol. 15, July 2015. Doi: 10.7718/ijec.v15i1.1005https://www.researchgate.n et/publication/283199865_Phenotypic_Characteriz ation_of_Native_Chickens_Gallus_gallus_domesti cus_in_Eastern_Samar_Philippines

[9] A. J. Salces, L. M. Quirog, and E.D. Chatto, 2013. "Participatory approach in definition of breeding objective traits for Boholano strain of native chicken”. Philipp J Vet Anim. Sci. 39(2): 165-172. https://www.pjvas.org/index.php/pjvas/article/view $15 / 4$

[10] A. J. Salces, M.G.N. Yebron Jr., C. B. Salces, and J. M. D. Dominguez, "Phenotypic and genetic characteristics of Boholano genetic group of Philippine native chicken (Gallus gallus domesticus, L)", Philipp J Vet Anim Sci 2015, 41(1):

$1-11$ https://www.pjvas.org/index.php/pjvas/article/view 190/83

[11] J. Smyth, 1990. "Genetics of plumage, skin, and eye pigmentation in chicken". In: Crawford RD ed. Poultry Breeding and Genetics. Amsterdam: Elsevier Science Publishers

[12] F. Yeh F, R. C. Yang, and T. Boyle, 1997. POPGENE, the User-Friendly Shareware for Population Genetic Analysis. Molecular Biology and Biotechnology Centre, University of Alberta, Edmonton. 